i. Özdemir (2014). Edgar Allan Poe'nun "Annabel Lee” adlı şiirinin Melih Cevdet Anday tarafından yapılan çevirisine eleştirel bir çözümleme. Ana Dili Eğitimi Dergisi, 2(4), 16-31.

Ana Dili Eğitimi Dergisi
Journal of Mother Tongue Education
ADED - JOMTE
www.anadiliegitimi.com

\title{
Edgar Allan Poe'nun “Annabel Lee” Adlı Şiirinin Melih Cevdet Anday Tarafından Yapılan Çevirisine Eleştirel Bir Çözümleme
}

\author{
ihsan ÖZDEMIR ${ }^{1}$
}

Özet

Bu yazıda Amerikalı şair Edgar Allan Poe'nun (1809-1849) “Annabel Lee" adlı şiirinin Melih Cevdet Anday (1915-2002) tarafından Türkçeye yapılan çevirisi, doküman inceleme tekniği kullanılarak ve orijinal metinle karşılaştırmak suretiyle anlam ve üslup eşdeğerliği açısından incelenmiştir. Bunun için, incelenen şiirin çevirisine özgü zorluklar ve Anday'ın bu zorlukları aşmak için çeviri sürecinde başvurduğu yerlileştirme stratejisi ayrıntılı şekilde betimlenmeye çalışılıışır. Özgün metne kıyasla çeviri metinde gözlemlenen farklılıklar ve bunların oluşma sebepleri üzerinde de ayrıca durulmuştur. Buna göre erek metinde, kaynak metne göre anlam ve üslup açısından meydana gelen değişiklikler "deyiş kaydırmaları" olarak değil, "kayıp" olarak değerlendirilmiştir.

Anahtar Sözcükler: Eşdeğerlilik, Çeviri, Şiir, Kayıplar, Yaratıcı Aktarım

\section{A Critical Analysis Of The Translation By Melih Cevdet Anday Of Edgar Allan Poe's "Annabel Lee"}

\begin{abstract}
In this study, the Turkish translation by Melih Cevdet Anday of the poem "Annabel Lee" by the American poet Edgar Allan Poe has been examined in comparison with the original text in terms of semantic and stylistic equivalence using the document review technique. To this purpose, an effort has been made to describe in detail the difficulties peculiar to the translation of this poem as well as Anday's translation strategies to cope with these difficulties. The differences observed in the translation in comparison with the original text and the reasons for them have further been elaborated. The changes in the target text as compared with the source text have consequently been considered to be "losses" rather than "shifts of expression".
\end{abstract}

Keywords: Equivalence, Translation, Poetry, Losses, Creative Transposition

\footnotetext{
${ }^{1}$ Öğr. Gör., Abant İzzet Baysal Üniversitesi, Eğitim Fakültesi, Yabancı Diller Eğitimi Bölümü. Bolu. Doktora Öğrencisi, Sakarya Üniversitesi, Sosyal Bilimler Enstitüsü, Çeviribilim ABD. Sakarya. E-posta: ihsanozdemir30@hotmail.com
} 


\section{Giriş}

Şiirin bir dilden bir başka dile çevrilebilir olup olmadığı, öteden beri tartışıla gelmiştir. Zira düz yazıdan farklı olarak imgeler, çağrışımlar ve yan anlamlarla örülüdür şiir. Buna vezin, kafiye, vb, biçimsel farklııkları da eklemek gerekir. Ayrıca şiirde kültüre özgü öğelerin de bir hayli ağırıklı olduğu söylenebilir. Tüm bunlar şiir çevirisini güçleştiren etkenlerdir.

Her ne kadar şiir çevirileri en az 2000 yıldır kabul gören bir uygulama olarak yapıla gelse de, günümüze kadar gelen kuramsal tartışmalar çoğunlukla şiirin çevrilmesinin mümkün olup olmadığı hususuna odaklanmıştır (Connolly, 2005: 170-171).

Bu güçlük şiir çevirilerinin eleştirileri için de söz konusudur. Bilindiği gibi, Türkçede çeviri şiirleri inceleyen eleştiri yazıları yeterince kaleme alınmamıştır. Oysaki alanda bu tür eleştirilere intiyaç vardır. Bu çalışmada amaç, şiir çevirilerinin zorluklarına dikkat çekerken, okuru bu çevirilere eleştirel bir gözle bakmaya ve mümkünse metinleri asıllarıyla karşılaştırmaya yöneltmek ve çevirilerde meydana gelen kayıplara yönelik okur farkındalığını yükseltmektir.

Bu çalışmada "Annabel Lee" adlı şiirin aslının İngilizcede uyandırdığı etki ile çevirisinin Türkçede uyandırdığı etki, çeviri sürecinde gerçekleşen değişiklikler perspektifinden ele alınmıştır.

\section{Çeviride Eşdeğerlik}

Eşdeğerliliği bir kaynak metin ile erek metin arasındaki ilişki olarak tanımlamak mümkün. Armstrong (2005: 45) çeviride eşdeğerliliğin sürekli yeniden yorumlanan bir terim olduğunu söylerken, aynı paralelde Kenny (2009: 96) de çeviride eşdeğerliliğin ihtilaflı bir kavram olduğunu belirtmektedir.

Bu çalışmada, çeviribilimde eşdeğerlilikle ilgili var olan görüşleri bu kavramı reddeden, kabul eden ve bu kavrama farklı yaklaşan görüşler olarak basitçe üç kategoride inceleyeceğiz.

\section{Eşdeğerliliği Reddeden Bazı Yazarlar}

Snell-Hornby (1995: 13)'nin kitabında yer alan "Eşdeğerlilik Yanılsaması" alt başlığı çeviride eşdeğerlilik kavramının bir yanılsamadan ibaret olduğu ön kabulünü içermektedir. Ona göre, eşdeğerliliğin çeviri kuramında temel bir kavram olarak görülmesi doğru bir tutum değildir. Zira eşdeğerliliğin tam olarak ne olduğu kesin bir şekilde tanımlanmış değildir ve bu kavram diller arasında bir simetri olduğu "yanılsama"sına yol açmaktadır ki bu tür bir simetrinin varlığının gerçekle pek alakası yoktur (1995: 22).

Snell-Hornby eşdeğerliliği savunanların "miyop" bir bakış açısına sahip olduklarını söylemektedir (1995: 25). Ayrıca yazar kavram için "tutarsız" kelimesini kullanmaktadır (1995: 26).

Gentzler (2001: 4) bir çevirinin iyi ya da kötü, doğru ya da yanlış veyahut eşdeğer olması ya da olmaması yönünde hüküm veren ölçütlerin, çevirinin farklı uygulamaları ile kültürlerarası alışveriş niteliğine kısıtlamalar getirdiğini ve geleneksel çeviri anlayışının dışında kalan yaklaşımların değerini 
Edgar Allan Poe'nun “Annabel Lee” Adlı Şiirinin Melih Cevdet Anday Tarafından Yapılan Çevirisine Eleştirel Bir Çözümleme

azalttığını belirtmektedir. Gentzler çeviribilimde eşdeğerlilik kavramını alana zarar verdiği gerekçesiyle reddetmektedir.

\section{Eşdeğerliliği Kabul Eden Bazı Yazarlar}

Catford (1965: 49-55) çeviride eşdeğerliliği mümkün kılan koşulları tartışmakta ve bunu tartışmakla da bu kavramın çeviribilim için geçerli bir kavram olduğunu savunmuş olmaktadır. Newmark (1981: 39)'ın “orijinal metnin okurlarında yarattığına olabildiğince yakın bir etkiyi kendi okurlarında yaratmaya çalışan" çeviri türü olarak tanımladığı "iletişimsel çeviri”nin de eşdeğerlilik kavramıyla örtüştüğü görülmektedir.

En iyi çevirinin "çeviri gibi durmayan çeviri" olduğunu söyleyen Nida ile Taber (1982: 12) çevirmenin eşdeğerlilik uğrunda ciddi çaba sarf etmesi gerektiğini ifade etmektedirler. Nida ile Taber (1982: 22-24) ayrıca "devingen eşdeğerlilik" ve "biçimsel eşdeğerlilik" olarak adlandırdıkları iki eşdeğerlilik türünden ilkini sonrakine üstün tutmaktadırlar. Devingen eşdeğerlilik, bu yazarlara göre, mesaja'alıcı dil'deki 'alıcı'lar tarafından verilen tepkinin o mesaja 'kaynak dil'deki 'alıcı'ların verdiği tepkiyle ne derece örtüştüğüyle ilgilidir. Dolayısıyla, söz konusu olan, "biçimsel eşdeğerlilik"te olduğu gibi kaynak metnin biçimsel özelliklerinin ve iletisinin çeviride aynen korunması değil, kaynak metne kaynak dildeki 'alıcı'ların verdikleri tepkinin çeviri metnine erek dildeki 'alıcı'lar tarafından da büyük ölçüde verilmesinin sağlanmasıdır.

Çeviri de eşdeğerlilik kavramının geçerliliğini kabul eden Koller (1992: 216) de (Prunĉ, 2002: $65)^{\prime}$ in aktardığına göre çeviride beş tür eşdeğerlilikten söz etmektedir. Bunlar:

1-) Düzanlamsal eşdeğerlilik, 2-) Yananlamsal eşdeğerlilik, 3-) Metin türü gelenekleriyle ilgili eşdeğerlilik, 4-) Dil kullanımsal eşdeğerlilik, 5-) Ve biçimsel eşdeğerliliktir.

\section{Eşdeğerlilikle İlgili Diğer Görüşler}

Pym (2010: 37)' göre diller arasında mükemmel eşdeğerlilik diye bir şey söz konusu değildir; mevzubahis olan her zaman için "varsayılan eşdeğerliliktir".

Toury (2012: 32, 85) çeviribilimde eşdeğerlilikten "kurtulmak" isteyen bazı çağdaş yaklaşımlara karşı bu kavramı tekrar gözden geçirmek şartıyla muhafaza etmekten yanadır. Toury klasik tanımı bir kenara bırakır ve eşdeğerliliğin türlerinin ve gerçekleşme derecesinin olduğundan bahseder. Ona göre eşdeğerlilik her halükarda çeviri normları tarafından belirlenir.

Stolze (2013: 122)'ye göre, "bir erek metin (sadece belirli metin düzeyleri bakımından!) bir kaynak metnin eşdeğeri sayılabilir. Dillerin ve kültürlerin farklııklarından dolayı, farklı düzlemlerdeki tek tek unsurlar genellikle değişmez ve tümü aynı anda eşdeğer kabul edilemez." 


\section{Şiir Çevrilebilir mi?}

Şiirin çevirisini pek mümkün görmeyen bazı görüşler kısaca şöyle özetlenebilir:

Nabokov (1955: 155) Pushkin'in manzum romanı Eugene Onegin'in Rusçadan İngilizceye manzum şekilde (dipnotsuz) çevrilemeyeceğini savunur Açıkçası Nabokov bu eserin Rusçadan Ingilizceye ancak düzyazı olarak aktarılabileceğini söylemektedir.

Demirezen'in (1991: 115) verdiği şu örnek, şiirde bir başka dile çevrilemeyen ögelerin var olduğunu destekler niteliktedir. Demirezen'e göre Tennyson, yansılama (onamotope) yöntemini şiirin anlamıyla bütünleştirebilen az sayıda şairden biridir. Bu görüşüne, şairin The Princess adlı şiirinde [m] sesini tekrar ederek arı vızıltısını taklit etmesini kanıt gösterir:

"The moan of the doves in immemorial elms

And murmuring of innumerable bees"

(Norton Anthology of English, s.856)

Şiirin herhangi bir dile çevirisinde bu aliterasyonu kayıpsız vermek belki imkânsız, imkânsız değilse bile gerçekten pek zor olsa gerektir.

Demirezen (1991: 124) her kültürün kendi değerlerini sözcüklerin içine sakladığını söyler. Mesela, Türk kültürüne özgü "Sağlık olsun.", "Geçmiş olsun.", "Sıhhatler olsun.", "Başınız sağ olsun." gibi ifadelerin İngilizce'de karşılıkları yoktur. Türkçedeki baldız, yenge, görümce ve elti gibi kavramlar içinse İngilizce'de sadece bir sözcük - sister-in-law - vardır. Şiirin de büyük ölçüde içinde doğduğu kültüre özgü ögeler içeren bir sanat olduğu söylenebilir.

Şiirde ritim, ölçü, sessel özellikler, eksiltili anlatım, vb, pek çok unsurun layıkıyla aktarılması neredeyse imkânsızdır. Altay (2001: 42), edebiyatçıların, özellikle de şairlerin, yapıtlarında alışımadık biçimler, bağdaştırmalar ve betimlemeler kullandıklarını, zaten şiiri şiir yapanın da bu farklı kullanımlar olduğundan bahsederken, şiirin çevrilemez bir tür olduğunu savunmaktadır".

Toklu (2003: 114) da büyük ölçüde benzer bir görüşü dile getirmektedir:

"Çağrışımsal anlam örgüsünde kültürel art-alanın ağır bastığı, [...] şiirlerin çevirisi sözcüksel düzlemde olasıysa da; kültürel art-alana dayalı çağrışım ekseninin erek dilde yeniden oluşturularak kaynak dildeki çağrışım ve imgelerin bütünüyle yansıtılması olanaksızdır."

Connolly (2005: 170-171) de şiirin öteki metinlere kıyasla çevirisi en zor metin türü kabul edildiğini belirtmektedir. Connolly’ye göre şiir, dilin en özlü ifadesidir ve şiirde düz anlamdan ziyade ağırlıklı olarak yan anlam vardır. Bu yüzden de şiir çevirisi düzyazı çevirisinden daha büyük zorluklar içermektedir. 


\section{Şiir Çevirisinde Kayıplar}

Şiir çevirilerinde kayıplar, şiirin tabiatı gereği, öteki metin türlerinin çevirilerine göre daha fazla olmaktadır. Mesela, R. Frost şiiri düpedüz"çeviride kaybolan (şey)" olarak tanımlamaktadır (http://www.goodreads.com/quotes/625-poetry-is-what-gets-lost-in-translation).

Bu tanımdan, şiiri şiir kılan tüm özelliklerin çeviride yitirildiği ya da bir başka deyişle, çeviride yitip giden nitelikler bütününün tam da şiiri şiir kılan şey olduğunu çıkarmak mümkündür. Kendi ifademizle söyleyecek olursak; her ne ki çeviride kaybolur, o şiirdir yahut her ne ki şiirdir, o çeviride kaybolur.

Karantay (1985: 153) çeviri süreci içinde oluşan kayıpların başında biçem kaybının geldiğini savunur.

"Yazarı yazar yapan biçemdir ilkesinden yola çıkan yaklaşımda, biçem aktarımı çetin iştir, çevirinin en güç yanıdır. Saygılı çeviri, kaynak metnin biçemini bütünüyle aktarmayı amaçlar".

Özellikle edebî çevirilerde üslubun aktarılması, yazarın kaynak dildeki üslubunun erek dilde de yaşatııması çeviride eşdeğerlik kavramı açısından büyük önem arz eder.

Popoviĉ (1970: 156-157) çeviride kayıp olgusunu kendisine ait "deyiş kaydırmaları" kavramıyla "Özgün metne göre yeni gibi görünen, ya da yeni gibi görünmesi gereken yerde öyle görünmeyen her şey, bir kaydırma olarak yorumlanabilir" şeklinde açıklamaktadır.

Demirezen (1991: 126) çeviride kayıpların kaçınılmaz olduğunu ve çevirinin az kayıpla kotarılabilmesi için çevirmene büyük görevler düştüğünü söyler. Bu noktada elbette ki çevirmenin işi zordur ve kendisinden sahip olduğu bilgi ve beceri donanımı doğrultusunda elinden gelen azami gayreti sarf etmesi beklenmektedir.

Popoviĉ́e (1970: 156-157) göre deyiş kaydırmaları çevirmenin kaynak metne sadık kalmak istememesinden değil, bilakis orijinal metnin anlamını muhafaza etme çabasından ileri gelmektedir.

"Çeviri sürecinin metnin anlamsal özelliklerinde kaydırmalar gerektirmesi, çevirmenin özgün metnin anlamsal çekiciliğini azaltmak istemesi olarak anlaşılamaz. Bunun tam tersidir doğru olan. Çevirmen özgün metnin "düzgü"sünü korumaya çabalar. Çevirmenin kaydırmalara başvurması, özgün metnin dizgesini çevirinin dizgesinden ayıran değiş̧ikliklere, iki dil ve konuyu sunma yolunda iki yöntemin gösterdiği ayrılıklara karşın, özgün metnin anlamsal özünü aktarmaya çabalamasındandır".

Paker (1983: 131) de benzer bir görüşü dile getirmektedir.

"...kaynak metne göre ayrılıklar gösteren bir çeviride ayrılıkları "yanlış" olarak değerlendirmek yerine çeviri etkinliğini bir süreç olarak ele almak ve bu süreç sırasında meydana gelen ayrılıkları çeviri etkinliğinin kendi yapısına göre tanımlamak ve betimlemek daha gerçekçi ve yararlı sonuçlara varılmasını sağlar". 
Şiir gerçekten de "erişilemez bir ülkedir" ve "kimse bu ülkeyi tümüyle keşfedememiştir (Özdemir, 2013: 329)”. Şiir çevirisinin güçlükleri pek çoktur.

\section{Çeviri mi, "Yaratıcı Aktarım” mı?}

Yukarıda anlatılanları destekler nitelikte, Jakobson'un da (1959) kati inancı şiirin tabiatı gereği çevrilemeyeceği yönündedir. Bu yüzden şiir sanatı söz konusu olduğunda çeviri değil, ancak "yaratıcı aktarım”ın mümkün olduğunu söyler. Bir başka deyişle, Jakobson şiirin hiçbir şekilde çevrilemeyeceğini, ancak bir başka dilde yeniden yaratılabileceğini düşünmektedir.

Newmark da (2003: 66) benzer bir görüşü savunur. Vasat bir şiiri çeviren iyi bir şair kaçınılmaz bir biçimde "yaratıcı sapma”lara başvuracaktır. Newmark'a göre, şiirde şiire özgü kısıtıııklar ne kadar çoksa (uyak, ölçü, asonans, aliterasyon, onamotope, vb.) "yaratıcı sapma"lara o kadar fazla ihtiyaç vardır.

\section{Inceleme Yöntemi}

Şiir çevirisinin zorluklarından bahsettikten sonra, şiir çevirilerine yönelik eleştirilerin de güç bir etkinlik olduğuna ve bu etkinliğin belli bir yöntem takip etmeyi gerektirdiğine değinmek gerekir.

Paker, (1983: 131) Eliot'ın "The Love Song of J. Alfred Prufrock" adlı şiirini ele aldığı çalışmasında, bu şiirin Türkçedeki üç ayrı çevirisini birbirleriyle ve şiirin aslıyla karşılaştırıp çeviriler arasındaki farklııkları Popovič́in "irdeleyici ve betimleyici" yöntemiyle değerlendirmiştir (Paker, 1983: 132). Paker'in bu incelemesi yöntem bakımından kendisinden sonra gelecek olan araştırmacılara ışık tutacak niteliktedir. Dolayısıyla bu çalışmanın çıkış noktası Paker'in inceleme yöntemi olmuştur. Bu çalışmanın Paker'in incelemesinden ayrılan yönü ise, kaynak metnin farklı çevirilerinin değil, tek bir çevirisinin - Türkçede en fazla bilinen çevirisinin - ayrıntılı bir şekilde ele alınmasıdır.

Ergülen, bu yazının inceleme konusunu teşkil eden metni şöyle övmektedir

"Şiiri bilirsiniz, sanki Türkçe bir hatıranın şiiri gibi 40 yıldır ezberimizdedir. Tümünü hatırlamasak da duygusu yeter, dizeleri alır götürür hepimizi yok yıllara, geçmiş ülkelere: 'Senelerce, senelerce evveldi/ Bir deniz ülkesinde/ Yaşayan bir kız vardı bileceksiniz/ ismi Annabel Lee/ Hiçbir şey düşünmezdi sevilmekten/ Sevmekten başka beni'. Edgar Allan Poe'nun şiirini Türkçeye kazandıransa büyük şairimiz Melih Cevdet Anday. Can Yücel'in 'Türkçe söylediği' şiirlerin güzelliğini biliyoruz ama, Anday da Can babadan geri kalmamış, belli (Ergülen, 2005)".

Bu metinle ilgili benzer bir görüş de aşağıdaki gibidir:

"Annabel Lee'nin Anday tarafından yapılan [çevirisi] öteki çevirileri" arasında ön plana [çıkmakta] ve ülkemizde "[en iyi annabel lee çevirisi]" ve "[shakespeare'nin 66 nolu sonesinin

\footnotetext{
${ }^{2}$ Remzi Şanlı'nın çevirisi için bkz: http://resanli.blogcu.com/annabel-lee-turkce-ceviri/2176443

Selçuk Bekâr'ın çevirisi için bkz: http://www.antoloji.com/annabel-lee-edgar-allan-poe-ceviri-selcuk-bekar-siiri/\#
} 
Edgar Allan Poe'nun “Annabel Lee” Adlı Şiirinin Melih Cevdet Anday Tarafından Yapılan Çevirisine Eleştirel Bir Çözümleme

can yücel çevirisi ve homeros'un ilyada'sının azra erhat çevirisiyle birlikte, dilimize yapılmış güzide çeviriler arasında]" kabul edilmektedir (https://eksisozluk.com/annabel-lee--60603).

Bu çalışmada doküman inceleme tekniği kullanılarak Amerikalı şair Edgar Allan Poe'nun (1809-1849) "Annabel Lee" adlı şiirinin Melih Cevdet Anday (1915-2002) tarafından Türkçeye yapılan çevirisi, aslıyla karşılaştırılarak, şiir çevirisini kuşatan güçlükler ekseninde anlam ve üslup eşdeğerliği bakımından ele alınmış ve bu doğrultuda betimleyici çözümlemeye tabi tutulmuştur.

Bu çerçevede, Anday'ın çevirisinde özgün metne göre kayıplar - Popoviĉ́'in tabiriyle "deyiş kaydırmaları" - tek tek saptanmış ve bunlar çevirmenin izlediği yerlileştirme stratejisi doğrultusunda açıklanmaya çalışıımıştır. Çalışma, kaynak metin ile erek metni yalnızca anlam ve üslup düzleminde karşılaştırmakla sınırlandırılmış, şiire özgü vezin, kafiye, vb., biçimsel ahenk unsurları incelemenin dışında tutulmuştur.

Bu araştırmada Poe'nun şiirinden Türkçeye araştırmacı tarafından yapılan çeviriler metnin düz çevirisi olmaktan ibarettir ve Türk okuruna orijinal metnin tam anlamını verme gayesi gütmektedir. Hiçbir surette şiir dizesi olmak iddiası taşımamaktadır.

\section{Bulgular}

"Annabel Lee" şiirinin İngilizce aslı ve Anday tarafından Türkçeye yapılan çevirisi Ek'te verilmiştir. Metnin aslı ve çevirisiyle ilgili yapılan analiz aşağıdaki gibidir:

I. Kita

Asıl metindeki "many and many a year ago" ifadesi İngilizcede eski bir kullanım kabul edilir ve bu haliyle şiire masalsı bir hava vermektedir. Çeviride karşılık olarak seçilen "seneler seneler evveldi" ifadesindeki "sene" kelimesi de, "yıl" kelimesinden farklı olarak, Türkçede sanki böyle bir eskiliği ve masalsılığı vermektedir. Ayrıca, kelimenin ikileme şeklinde tekrar edilmesi de, hem bu eskilik hissini perçinlemek hem de ifadenin aslına sadık kalmak bakımından isabetli olmuştur.

"kingdom" sözcüğünün "ülke" olarak çevrilmesi ise dizelerdeki ahengi yitirmeme çabasının bir sonucu gibi gözükmektedir. Sözcüğün dilimizdeki tam karşılığı "kralık"tır. Bu karşılığın tercih edilmemesi, çeviride anlam yitimine yol açmıştır; zira "ülke" ile "krallık" kelimeleri insana farklı şeyler çağrıştırmaktadır. "Krallık" kelimesi mesela insanı bir ortaçağ atmosferine götürebilmektedir.

"whom you may know" ifadesinin Türkçeye "bileceksiniz" diye çevrilmesi, akıcılı̆ıın ve "k" sesinden ileri gelen aliterasyonun yitirilmemesi uğruna tercih edilmiş gibi durmaktadır. Kaldı ki, "bileceksiniz" ifadesi Türkçede "bilirsiniz"e yakın, yaygın kullanılan bir ifadedir."bilebilirsiniz" diye çevrilseydi, muhtemelen aynı etkiyi yapmayacaktı. Ne var ki, "bileceksiniz"de ihtimalden ziyade kesinlik var gibi. Bu yüzden, özgün ifadedeki mananın bir ölçüde yittiği söylenebilir.

"By the name of ANNABEL LEE" ifadesinin "ANNABEL LEE adında/isminde" diye çevrilmediğini görüyoruz. Burada bir anlam kaybı değil, mevcut yapının -Türkçeye aynen aktarılabilecekken -

Uğur Demiröz’ün çevirisi için bkz: http://www.siirleraslabitmemeli.com/?p=4735 
değiştirilerek aktarılması söz konusu. Çevirmenin bu yolla dizelerin kendi içindeki ahengini koruma kaygısı güttüğü düşünülebilir.

Kaynak metnin üçüncü dizesinde yer alan "maiden" kelimesinin beşinci dizede de tekrarlanarak vurgulu bir anlatım yaratıldığını, fakat bu vurgunun erek metinde kaybolduğunu söylemek mümkün. "And this maiden" ifadesinin "Ve bu kız" şeklinde çevrilebilecekken hiç çevrilmemesi, çevirmenin şiirde az kelime kullanma çabasını akla getirmektedir (Kayhan, 1988: 30'dan akt. Durmuş, 2009: 1298) $)^{3}$

"With no other thought" ifadesinin "başka bir düşüncesi olmaksızın" şeklinde çevirisi mümkünken, bunun tercih edilmemesi ve "Hiçbir şey düşünmezdi" olarak çevrilmesi, herhangi bir anlam kaybına sebep olmazken; bir "söz öbeğinin" "cümle" gibi aktarılması üslupta da farklılığa sebep olmuştur.

Her ne kadar "live-yaşamak" sözcüğünün anlam olarak bağlamda içkin olduğu söylenebilirse de, bu kelimenin Türkçeye hiç aktarılmaması bir kayıp gibi de anlaşılabilir.

"Than to love and be loved by me." ifadesinin çevirisinde de iki yönlü kayıp söz konusudur. Şöyle ki; ilk olarak, "sevilmekten, Sevmekten başka beni." ifadesinde kaynaktaki sıra takip edilmemiştir. İkinci olarak da, şiirin aslındaki ifade "than to love me-beni sevmekten başka" ve "than to be loved by me-(benim) tarafımdan sevilmekten başka ya da benim onu sevmemden başka" gibi dilbilgisel açıdan ayrı ayrı doğru söyleyişlere dönüştürülebildiği halde, aynı şeyi çevirisine yaptığımızda, "sevmekten başka beni"de hiçbir sıkıntı yokken, "sevilmekten başka beni" şeklinde bir ifade kulağa yanlış gelmektedir. Burada, İngilizcesinde yapı açısından hiçbir sıkıntı çıkarmayan bir ifade, Türkçeye tam çevrildiğinde kelime fazlalığına yol açmakta ve çevirmenin karşısına bir zorluk olarak dikilmektedir. Bu yüzden de bu ifadenin kayıpsız çevirisi, şiiriyete kurban edilmiş izlenimi vermektedir.

II. Kita

"I was a child and she was a child," ifadesinin çevirisinde yine sıra takip edilmediği görülmektedir. Bu, anlam itibariyle bir kayıp değilse de, üslup bakımından bir farklılıktır.

"In this kingdom by the sea;" birebir çevrilecek olsa, "Deniz kıyısındaki/kenarındaki bu krallıkta;" olurdu. Anday'ın burada da üslup değişikliğine gittiği açıktır. Ayrıca, "memleketimiz" gibi, şiirin aslında geçmeyen bir kelimenin kullanılmasını, çeviri metni erek kültür okuruna duygusal yönden yaklaştırma çabası olarak görülebilir. "Kingdom" bahsine ise yukarıda değinilmişti.

"But"ın çevrilmemesiyle anlam yönünden bir kayıp oluşmuştur. Zira "but" ile bir tezat vurgulanmaktadır. Bu âşılar küçük yaşlarına rağmen birbirlerine büyük bir aşkla tutkundurlar. "we loved with a love that was more than love- aşktan öte bir aşkla sevdik/aşktan fazlası olan bir aşkla sevdik". Bu kısımda, Türk kültürüne özgü "karasevdalıık" kavramının çeviride yer alması, İngilizce

\footnotetext{
3 “Edgar Allan Poe’dan çok şey öğrendim. Sözcük tasarrufunu öğrendim. Ne kadar az sözcükle, ne kadar büyük ve bizi şaşırtan duygular uyandırabiliyor, bunu anladım. Bu da biliyorsunuz, şiirin en büyük sorunlarından biridir”.
} 
metnin bu dizesinde mevcut olmayan bir takım arabesk hisleri çağrıştırdığı için, Poe'nun kastettiğinden farkıı bir anlamın çıktığı söylenebilir.

"With a love" ifadesinin çeviride hiç yer almaması, özgün metindeki yinelemeden kaynaklanan estetiğin ve vurgunun Türkçeye aktarılmamış olduğunu düşündürmektedir.

"the winged seraphs of heaven" ifadesi Türkçeye "cennetteki kanatlı büyük melekler" olarak çevrilebilir. Anday'ın çevirisinde "cennet" "gökler"e dönüşmüş, "büyük melekler" "melekler"e indirgenmiş, "kanat" imgesi de "uçan" ile karşılanmaya çalışılmıştır. "seraphs"ın sadece "melekler" diye çevrilmesi, sevenlerin aşkına bir nebze de olsa gölge düşürmüştür, çünkü metnin aslında şöyle bir ima vardır: birbirlerine o kadar âşıktılar ki, değil küçük melekler, büyük melekler bile onları kıskanmıştı. Çeviride bu ima kaybolmuştur. Kendisi de şair olan Anday, Poe'nun imgelerine yakın, fakat kendisine ait imgeleri tercih etmiş gibidir.

"her and me." "bizi" diye aktarılmış. Anlam kaybı yoksa da, söyleyiş açısından kayıp var.

III. Kita

"long ago"nun "bir gün" olarak çevrilmesinde de bir kayıp söz konusu. Zira bu ifade dilimize "uzun zaman önce/evvel" gibi aktarılır. Bu haliyle de daha masalsı olur.

Kaynak metinde "göze geldi" ifadesi hiç yer almıyor, dolaylı yoldan veriliyor. Hal bu iken, bu ifadenin doğrudan söylenmesi değil, çeviride de bir ima olarak kalması ve okurun bu yorumu erek metinden çıkarabilmesi, daha isabetli olurdu.

"A wind blew out of a cloud, chilling - My beautiful Annabel Lee;"nin "Üşüdü rüzgârından bir bulutun - Güzelim Annabel Lee;" şeklindeki aktarımında da şöyle bir üslup farklılığı söz konusu: İngilizcesinde bir buluttan rüzgâr esmiş ve Annabel Lee'yi üşütmüştür. Türkçesinde ise bir bulutun rüzgârından Annabel Lee üşümüştür. Cümlelerin özneleri farklılık arz etmektedir. Ancak mana yerli yerinde durmaktadır.

"highborn kinsman" dilimize hiç aktarılmamıştır. Oysaki buradan Annabel Lee'nin asil bir kan taşıdığını anlıyoruz. Ya da en azından şairin gözünde öyledir. "kinsman"daki tekil kullanımdan da, Annabel Lee'yi taşıyanın - muhtemelen kucakta - tek kişi olduğunu söylemek mümkün. Bu durumda "Götürdüler el üstünde" dizesi yanlış bir yorum gibi durmaktadır.

"Koyup gittiler beni," Türkçede halk diline yakın, Türk okurun kolaylıkla beğenebileceği bir ifadedir ve "onu benden alıp uzağa götürdüler" gibi düz bir anlatıma da bu yüzden tercih edilmiş gibidir. Ne var ki, "And bore her away from me,"deki nötr diyebileceğimiz söyleyiş Anday'ın metninde yitmiş, yerini sanki okurda bir acıma hissi uyandırma çabasına bırakmıştır.

"And bore her away from me, - To shut her up in a sepulchre" bu iki dize birlikte düşünülmeli, "onu benden alıp götürdü ve taştan bir mezara kapattı." şeklinde. Burada "sepulchre" hikâyenin geçtiği krallığın coğrafyası ve kültürü hakkında bizlere ipuçları vermektedir. Bu taştan bir mezardır ve muhtemelen kayalardan yapılmıştır. İngilizcesinden okuyanların zihninde muhtemelen kayalıkların hâkim olduğu bir deniz krallığı canlanmaktadır. O yüzden, bu kelimenin basitçe "mezar" diye çevrilmesi bu çağrışımların yitmesine sebep olmuştur."mezarı ordadır şimdi" şeklindeki aktarım da 
yine üslup farklılı̆ına yol açmıştır. Ayrıca, "şimdi”nin de kaynak metinde bir karşılığı yoktur ve metne ilave niteliğindedir.

IV. Kita

"daha bahtiyardık" ifadesi "çok daha bahtiyardık" diye çevrilseydi, "not half so happy"deki anlam daha iyi karşılanmış olacaktı. Zira burada sevgililerin aşklarının büyüklüğüne vurgu var yine. Çevirmenin kelime tasarrufuna yönelmesi, çeviride belli bir anlam kaybına yol açmış gibi.

(as all men know, - In this kingdom by the sea)"nin çevirisi "bu deniz krallığında/ki herkesin bildiği gibi" şeklinde. Anday ise burada bir kelime oyununa başvurmuş ve "deniz ülkesi"nin kendisini de şahit göstermiş. Ayrıca, "bilmek" ile "şahit olmak"ı eşdeğerde kabul etmiş ki bu pek doğru sayılmaz.

"Chilling and killing my Annabel Lee." dizesi "Üşüdü gitti Annabel Lee". diye aktarılmış. Buradan kaynak metindeki "üşüttü ve öldürdü/ölümüne sebep oldu" anlamı pek çıkmamaktadır. "Üşüdü gitti” ifadesi kesin bir ölüm ifadesi değildir. Anlam sanki havada kalmıştır.

"my Annabel Lee."de "my-benim" çevrilmemiş.

V. Kita

Illk üç dizedeki çok sayıdaki üslup farklılıklarını tek tek dile getirmek zor gözükmektedir. Anday bu dizeleri çevirmemiş, şairane bir söyleyişle Türkçede adeta yeniden yazmıştır denebilir. "Yaşşa başşa ileri"nin Türkçedeki "yaşını başını almak" deyimine bir öykünmeyle Anday tarafından üretildiğini tahmin ediyoruz. "older/wiser than" ifadesini karşılamak için pratik bir çözüm gibi durmaktadır.

"Geçemezlerdi bizi"nin "stronger by far than ile of many far wiser than" gibi güçlü karşılaştırma belirten ifadeleri yeterince karşılamadığı görülmektedir.

"yedi kat gök" ifadesi "heaven above" demek değildir tam olarak, ancak Türkçede kulağa hoş gelen, yaygın bir deyiştir ve bu yüzden seçilmiş gibidir. "yukarıdaki/gökteki/gökyüzündeki cennet" gibi bir kullanım yavan kaçabilirdi çünkü.

"deniz gibi cinleri" "denizin dibindeki cinler"den pek de uzak değildir ve akıcılık açısından iyi bir çözüm gibi durmaktadır.

"Can ever dissever my soul from the soul - Of the beautiful Annabel Lee." "Ruhumu güzel Annabel Lee'nin ruhundan ayıramaz asla." diye çevrilebilir. Anday'ın çevirisinde "ruh" kelimesi geçmeliydi aslında, zira şiirin neredeyse en duygu yüklü dizeleri bunlar. "Ruh" sözcüğü bu dizelerin de ruhu bir bakıma.

"Hiçbiri" metnin aslında yok. Türkçesine vurgu katmak için eklenmiş gibi duruyor. 
"the beautiful Annabel Lee."nin çevirisi "güzel Annabel Lee." Anday burada "Güzelim Annabel Lee" diyerek III. Kıtadaki "my beautiful Annabel Lee" dizesini tekrar etmektedir. Aslında bu dizenin de tam çevirisi "benim güzel Annabel Leem" şeklindedir.

VI. KIta

"For" hiç aktarılmamış. Hâlbuki önceki kıtayla sebep sonuç ilişkisi kurmakta. İki ruhu niçin hiçbir şeyin birbirinden ayıramayacağını açıklamakta. "For the moon never beams without bringing me dreams - Of the beautiful Annabel Lee;" gerçekte şu demek: "Zira bana güzel Annabel Lee"nin hayalini getirmedikçe, ay asla parıldamaz;" Bu da şu şekilde yorumlanabilir: "Zira ay ne zaman parıldayacak olsa, bana güzel Annabel Lee'nin hayalini getirir;" Anday'ın metni ise şöyledir: "Ay gelip ışır, hayalin erişir - Güzelim Annabel Lee;" Anday'ın şiirde üslubu yaratan temel öğelerden biri olan tümce yapılarını göz ardı ederek, dizelerin mealini özetlediği söylenebilir. Gerçi Türkçesindeki bu yalınlıkta da bir güzellik vardır. Fakat bunun Poe'nun o güçlü anlatıma denk düştüğünü söylemek zordur.

Benzer bir durum "And the stars never rise but I feel the bright eyes - Of the beautiful Annabel Lee;" dizeleri için de geçerlidir. "Ve yıldızlar ne vakit çıksa/yükselse, güzel Annabel Lee'nin o ışıl ışıl

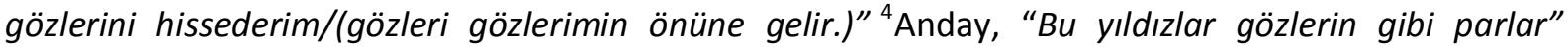
diyerek, "gökteki yıldızların, şaire sevgilisinin gözlerini hatırlattığı gerçeği"ni yine yalın bir söyleyişle ifade etmiştir. Burada halkın diline inmek gibi bir kaygı güdüldügünü söylemek mümkündür. Ne var ki, bu kaygı Poe'nun üslubunun çeviride muhafaza edilememesine sebep olmuştur.

"night-gece" kelimesi "gecelerim"e yedirilmişse de, "tide--gelgit/med-cezir" sözcüğünün dilimize hiç çevrilmediği gözden kaçmamaktadır.

"I lie down by the side" için "uzanır beklerim" doğru bir karşlıı gibi gözükmektedir. Zira "beklemek" kelime olarak kaynak metinde mevcut değilse de, "all the night-tide -- tüm gece akıntısı/gelgiti boyunca"da anlam itibariyle içkindir.

Ingilizcesinde "Of my darling, ..." yani "Sevgilimin yanında (uzanır beklerim)" iken anlam, Türkçesinde "Sevgilim, ..." şeklinde doğrudan bir hitaba dönüşmüştür. Bir başka deyişle, burada işlevsel eşdeğerlik yoktur.

"my life and my bride"taki "and-ve" çeviride fazlalık olarak görülmüş ve metne konmamıştır. Yine Anday'ın az kelime kullanma gayreti gözlemlenmektedir.

Metnini Türk kültürüne özgü kılma çabası güden Anday'ın "my bride"ı "karım" diye çevirmek varken, "gelinim" diye aktarması kulağa yadırgatıcı gelmektedir. İngiliz ya da Amerikan kültüründe yeni evli bir erkek karısına "my bride" diye hitap edebilirken, kültürümüzde bu hitap "eşim/karım/hanımım" şeklindedir. Zira bizde "gelinim", kayınvalide ya da kayınpederin kullanacağı bir hitaptır.

\footnotetext{
${ }^{4}$ Parantez içerisinde verdiğimiz, Poe'nun kastettiğini düşündüğümüz anlamdır.
} 
"sepulchre" "yattığın yer" diye verilmiş. Poe şiirin sonunda bu sözcüğü tekrar etmekte bir sakınca görmemişken, Anday'ın bundan kaçınması pek doğru değil gibi. "tombmezar/kabir/lahit/türbe" kelimesinin karşılığı da yok. Ayrıca bu dizelerde - "Orada, deniz kenarındaki taş mezarda, - tınılayan denizin kenarındaki kabrinde." - üslubu farklılaştıran yapısal değişiklikler de söz konusudur yine.

Son olarak, "sounding" için "azgın" karşılığı abartılı durmaktadır. Zira metnin bütününde hep fırtınalı bir denizden bahsedildiğine dair yeterli kanıt yoktur. Kelimenin sözlük anlamı da böyle bir yoruma kapı aralamamaktadır. III. ve IV. kıtalarda bahsi geçen ve Annabel Lee'nin ölümüne yola açan soğuk rüzgâr, Anday'ı böyle düşünmeye sevk etmiş olabilir. Oysaki bu ses - Annabel Lee'nin kabri deniz kenarında olduğuna göre - gelgitten kaynaklanan ninnimsi bir tını olabilir. O yüzden sadece "dalga sesleri" diye de çevrilebilir.

\section{Sonuç}

Bu çalışmada görülmüştür ki, Poe'nun "Annabel Lee” adlı şiirinin Anday tarafından dilimize yapılan çevirisinde karşımıza belli kayıplar çıkmaktadır. İngilizce ve Türkçe arasındaki yapısal ve kültürel farklılıklardan ötürü bu kayıpların kaçınılmaz olduğu söylenebilir. Zaman zaman bu ayrılıklar Anday'ı Popović̂́in ifadesiyle "deyiş kaydırmaları"na yöneltmiştir.

Popoviĉ (1970: 156-157) deyiş kaydırmaları diye adlandırdığı kaynak ve erek metinler arasındaki farklııkları çevirmenin metnin aslına sadık kalma çabasından kaynaklandığını söylüyor ve bunları kayıp olarak nitelemiyordu. Benzer bir şekilde, Paker de bu tür ayrılıklara kayıp gözüyle bakmıyordu.

Çevirmenin çeviri sürecinde aldığı kararların betimlenmesini ve çözümlenmesini elbette gereklidir. Ne var ki, bir çeviri etkinliği neticesinde orijinal metne kıyasla çeviri metinde meydana gelen değişiklikleri deyiş kaydırmaları olarak nitelemekten ziyade kayıp olarak tanımlamak gerektiğini düşünüyoruz. Çünkü metnin çevirisinde aslına kıyasla gerçekten de kaybolan bir şeyler vardır. Anday'ın "Annabel Lee" çevirisi için Bulgular kısmında dile getirilen tespitler de bu görüşü destekler niteliktedir. Zira Anday bu şiiri Türkçeye aktarırken fazlaca yerlileştirmeler yapmış ve kendi üslubunu - Poe'nun üslubunu yitirmek pahasına - yer yer ön plana çıkarmıştır. Neticede Türkçede halk diline yakın, akıcı ve etkileyici bir metin ortaya çıkmışır. Fakat özgün metnin ruhundan da pek çok şey yitmiştir.

Bu netice aslında tabiidir. Zira şiir kendisini vücuda getiren millete aittir ve taşıdığı kültürel öğelerden ayrı düşünülemez. Bu açıdan şiir, Frost'un da dile getirdiği gibi, "çeviride kaybolan (şey)"dir (http://www.brainyquote.com/quotes/quotes/r/robertfros101675.html).

Connolly de aynı noktaya dikkat çekmektedir. Zira şiirin mesajı çoğu kez açıktan söylenmez, ima edilir; farklı okumalara ve çoklu yorumlara açıktır. Şu halde çevirmenin çevirdiği, kendi yorumudur (Connolly, 2005: 173).

Connolly çözümün, çevirmenin kaynak metnin "kurtarabildiği kadarını kurtarması" ve bu amaçla uygun stratejiler geliştirmesinde yattığını düşünür (Connolly, 2005: 171). Deyiş kaydırmalarının işte böyle bir strateji üretme çabasının sonucu olduğunu söylemek mümkündür. 
Hâlbuki "kurtarılabilenler" "kurtarılamayanlar"ın varlığına zorunlu olarak işaret etmektedir ve hangi çeviri stratejisi uygulanırsa uygulansın, bu değişmeyecektir. Bilhassa şiir çevirisi için bu böyledir.

Bütün bu tartışmaların ışı̆̆ında “Annabel Lee"nin M.C. Anday tarafından kaleme alınan Türkçesinin bir çeviriden ziyade, bir "yaratıcı aktarım" (Jakobson, 1959) olduğunu ve kaynak metinden "yaratıcı sapma"lar (Newmark, 2003: 66) içerdiğini söylemek mümkündür. Newmark vasat bir şiirin çevirisinde yetenekli bir çevirmenin "yaratıcı sapma"lara başvuracağı söylüyordu. İyi bir şiirin çevirisinde de bu tür sapmalara başvurulacağı, şiirin tabiatı gereği, aşikârdır. Bu sapmalara, "yaratıcı" oldukları için, kaynak ve erek metinler arasında anlam ve üslup açısından tam bir eşdeğerliliğin gözetilemeyeceği gerçeğinin kanıtı olarak bakılabilir.

Çeviribilim alanında şiir çevirisi eleştirilerine intiyaç vardır. Zira bu tür çalışmalar okurda bu çeviri türüne yönelik eleştirel bir bakışı geliştirmeye ve okura çeviri metinleri asıllarıyla karşılaştırma alışkanlığı kazandırmaya katkı sağlayacaktır.

\section{Kaynakça}

Altay, Ayfer. (2001). Şiir Çevirisinde Çevrilemeyenler. Hacettepe Üniversitesi Edebiyat Fakültesi Dergisi. Cilt 18. Sayı 1. s. 29-43.

Armstrong, Nigel. (2005). Translation, Linguistics, Culture_A French-English Handbook. Multilingual Matters Ltd. Clevedon, Buffalo, Toronto.

Connolly, David. (2005). Poetry Translation. Routledge Encyclopedia of Translation Studies. London \& New York; Routledge. Ed. Mona Baker. 170-176.

Demirezen, Mehmet. (1991). Çeviride Kayıplar Sorunu. Çeviribilim ve Uygulamaları Dergisi_Journal of Translation Studies, 115-128, Hacettepe Üniversitesi Mütercim-Tercümanlık Bölümü.

Ergülen, Haydar. (2005). Annabel Lee. Radikal Gazetesi_ 28 Aralık Çarşamba.

Gentzler, Edwin. (2001). Contemporary Translation Theories. Rev. 2nd Ed. Multilingual Matters Ltd.

Jakobson, Roman. (1959). On Linguistics Aspect of Translation at

http://culturalstudiesnow.blogspot.com/2011/10/roman-jakobson-on-linguistic-aspects-of.html Erişim tarihi: 21.09.2014

Karantay, Suat. (1985). Çeviri Öğretiminde Biçem Aktarımı, Dün ve Bugün Çeviri. Metis Çeviri Kitap 2, 153-162.

Kayhan, Nalan. (1988). Bir Şiir Virtüözü. Elele, S. 1, Ocak 1988, s. 30.

Kenny, Dorothy. (2009). Equivalence. Routledge Encyclopedia of Translation Studies. London \& New York; Routledge. Ed: Mona Baker. 96-99.

Newmark, Peter. (1981). Approaches to Translation. Pergamon. Oxford and New York.

Mitat, D. (2009). Yaşamsal ve Metinler Arası Bağlamda Melih Cevdet Anday Şiirinin Kaynakları. Turkish Studies_International Periodical For the Languages, Literature and History of Turkish or Turkic: Volume 4/1-II Winter 2009, 1298. doi:10.7827/TurkishStudies.585

Nabokov, Vladimir. (1955). Problems of Translation: Onegin in English. The Translation Studies Reader. Ed: Lawrence Venuti. 3rd ed. Routledge, 2012. 
Newmark, Peter. (2003). No Global Communication Without Translation. Translation Today: Trends and Perspectives. Eds: Gunilla Anderman and Margaret Rogers. Multilingual Matters Ltd.

Özdemir, İhsan. (2013). Ihsan Özdemir. Bolu Kültür ve Sanat Divanı_Diyorlar ki. Ed: Zeki Gürel. T.C. Bolu Valiliği il Kültür ve Turizm Müdürlüğü yayınları.

Paker, Saliha. (1983). Çeviride "Yanlış/Doğru" Sorunu ve Şiir Çevirisinin Değerlendirilmesi. Yazko Çeviri Dergisi, Sayı 13, Temmuz-Ağustos, s. 131-139.

Popoviĉ, Anton. (1970). The Concept "Shift of Expression" in Translation Analysis. Çev: Yurdanur Salman. Yazko Çeviri Dergisi, Sayı 1, Temmuz-Ağustos, 1981, s. 156-157.

Prunĉ, Erich. (2002). Einführung in die Übersetzungswissenschaft. 2nd erweiterte und verbesserte Auflage. Graz Translation Studies.

Pym, Anthony. (2010). Exploring Translation Theories. Routledge.

Snell-Hornby, Mary. (1995). Translation Studies_An Integrated Approach. John Benjamins Publishing Company. Rev. Ed.

Stolze, Radegundis. (2013). Çeviri Kuramları -Giriş- Çev. Emra Durukan. Değişim Yayınları.

Toklu, M. Osman. (2003). Şiir Dili ve Çevirisi. Akçağ yayınları.

Toury, Gideon. (2012). Descriptive Translational Studies - and Beyond. 2nd exp. ed. John Benjamins B.V. http://www.goodreads.com/quotes/625-poetry-is-what-gets-lost-in-translation Erişim tarihi: 21.09.2014 http://www.brainyquote.com/quotes/authors/e/edgar allan poe.html Erişim tarihi: 21.09.2014

https://eksisozluk.com/annabel-lee--60603 Erişim tarihi: 21.09.2014

http://resanli.blogcu.com/annabel-lee-turkce-ceviri/2176443 Erişim tarihi: 21.09.2014

http://www.antoloji.com/annabel-lee-edgar-allan-poe-ceviri-selcuk-bekar-siiri/\# Erişim tarihi: 21.09.2014

http://www.siirleraslabitmemeli.com/?p=4735 Erişim tarihi: 21.09 .2014 
Edgar Allan Poe'nun “Annabel Lee” Adlı Şiirinin Melih Cevdet Anday Tarafından Yapılan Çevirisine Eleştirel Bir Çözümleme

Ek

Annabel Lee

It was many and many a year ago,

In a kingdom by the sea,

That a maiden there lived whom you may know

By the name of ANNABEL LEE;

And this maiden she lived with no other thought

Than to love and be loved by me.

I was a child and she was a child,

In this kingdom by the sea;

But we loved with a love that was more than love-

I and my Annabel Lee;

With a love that the winged seraphs of heaven

Coveted her and me.

And this was the reason that, long ago,

In this kingdom by the sea,

A wind blew out of a cloud, chilling

My beautiful Annabel Lee;

So that her highborn kinsman came

And bore her away from me,

To shut her up in a sepulchre

In this kingdom by the sea.

The angels, not half so happy in heaven,

Went envying her and me-

Yes!- that was the reason (as all men know,

In this kingdom by the sea)

That the wind came out of the cloud by night,

Chilling and killing my Annabel Lee.

But our love it was stronger by far than the love

Of those who were older than we-

Of many far wiser than we-

And neither the angels in heaven above,

Nor the demons down under the sea,

Can ever dissever my soul from the soul

Of the beautiful Annabel Lee.

For the moon never beams without bringing me dreams

Of the beautiful Annabel Lee;
Annabel Lee

Seneler, seneler evveldi;

Bir deniz ülkesinde

Yaşayan bir kız vardı,

bileceksiniz

Ismi Annabel Lee;

Hiçbir şey düşünmezdi

sevilmekten

Sevmekten başka beni.

O çocuk ben çocuk,

memleketimiz

O deniz ülkesiydi,

Sevdalı değil karasevdalıydık

Ben ve Annabel Lee;

Göklerde uçan melekler bile

Kıskanırdı bizi.

Bir gün işte bu yüzden göze

geldi,

O deniz ülkesinde,

Üşüdü rüzgârından bir bulutun

Güzelim Annabel Lee;

Götürdüler el üstünde

Koyup gittiler beni,

Mezarı ordadır şimdi,

O deniz ülkesinde.

Biz daha bahtiyardık

meleklerden

Onlar kıskandı bizi,

Evet!_bu yüzden (şahidimdir

herkes

Ve o deniz ülkesi)

Bir gece bulutun rüzgârından

Üşüdü gitti Annabel Lee.

Sevdadan yana kim olursa

olsun,

Yaşça başça ileri

Geçemezlerdi bizi;

Ne yedi kat gökteki melekler, 


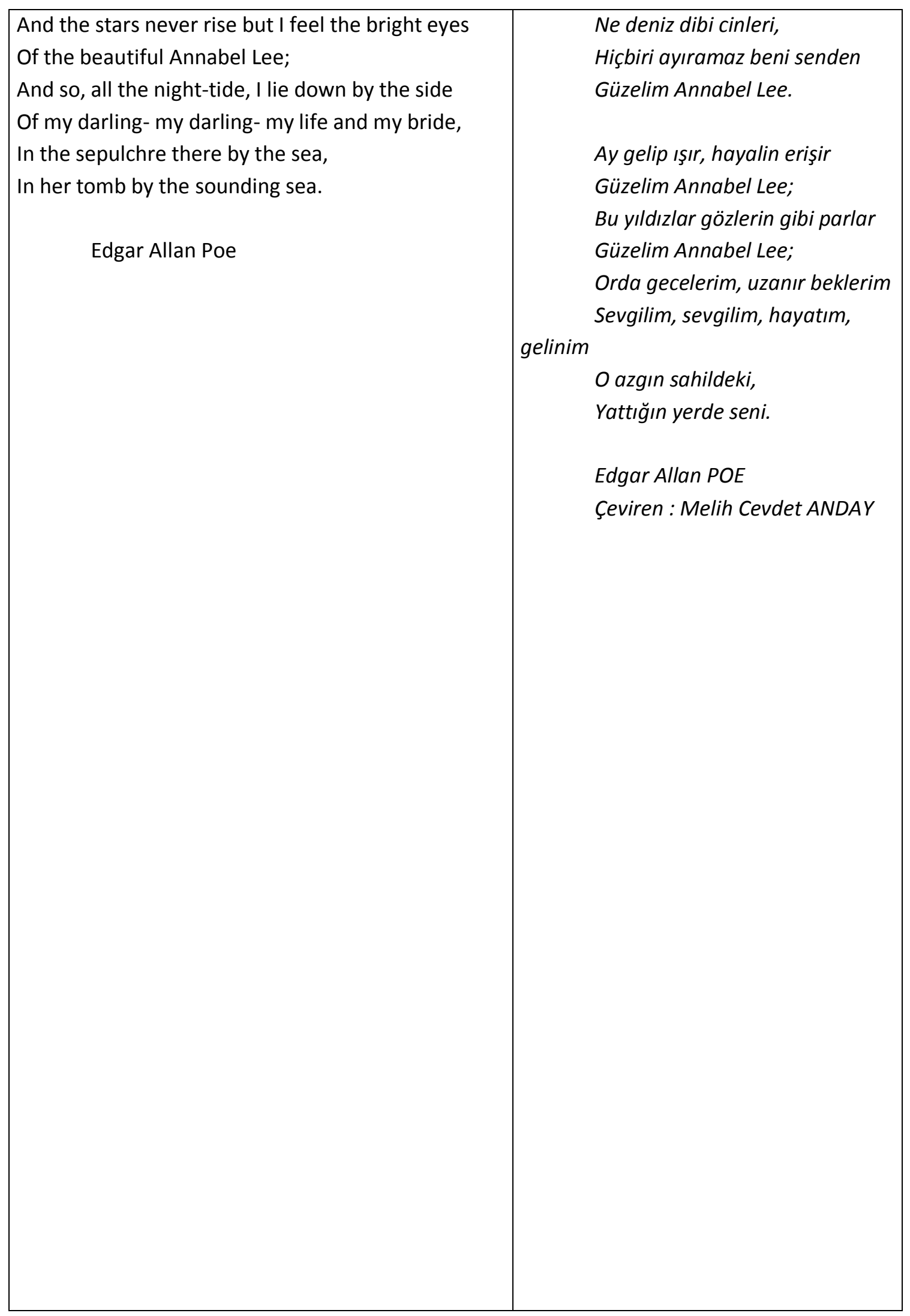

